Research Note

\title{
NEOLIBERALISM, CLASS AND CULTURE: THE 2008 FEDERAL ELECTIONS IN CANADA AND THE UNITED STATES
}

\author{
TIM FOWLER \\ Department of Political Science, Carleton University, Ottawa, Canada. ${ }^{1}$
}

\begin{abstract}
In the 2008 federal elections in Canada and The United States, conservative parties used class rhetoric in an attempt to draw votes from the working class. They did so by defining class along narrowly cultural lines, so excluding economic concerns. This research note examines the cases of 'Ordinary Canadians Don't Care About The Arts' and 'Joe the Plumber' to show how conservative parties in Canada and the United States are redefining class as a purely cultural variable. Although the rhetoric was not entirely successful, the cases are instructive about the ways that the understandings and importance of class as an economic relation is suppressed by pro-capitalist parties in political elections.
\end{abstract}

\section{Keywords}

class identity, cultural and economic dimensions of class, electoral politics, federal election

For many reasons, a party based in and enjoying the electoral support of the working class has never emerged in Canada nor the United States. Nor have questions of class become major sources of division in electoral politics. ${ }^{2}$ In both countries, the

\footnotetext{
${ }^{1}$ Tim Fowler has a BA in labour studies and an MA in Canadian politics, both from Brock University. He is currently pursuing a $\mathrm{PhD}$ in political science and political economy at Carleton University. His primary research concerns the changing political economy of manufacturing in North America, and how this has changed the politics of the Canadian Auto Workers. Contact information: Tim Fowler 1220 Merivale Road, Apt 614 Ottawa, Ontario K1Z 8P2; tim.timf@gmail.com.

2 The literature on why working class parties have not emerged in these two countries is extensive. Interested readers are directed to, for example, Archer (2007) Why is There No Labor Party In The United States; Goldner (2003) "On the Non-Formation of a Working-Class Political Party in the United States, 1900 - 45”; Lipset and Marks (2000) It Didn't Happen Here: Why Socialism Failed in the United States; 
electorally viable political parties are bourgeois parties with close ties to the capitalist class. The one possible exception to this is the New Democratic Party (NDP) in Canada, which has historic links with the Canadian labour movement. As with many social democratic labour parties worldwide, however, the NDP has shifted both its rhetoric and appeal to the "new middle class' ${ }^{3}$ rather than the working class. ${ }^{4}$ In the absence of working class parties it is perhaps not surprising that class, as such, did not appear to be a major issue in Canadian or American Federal elections of 2008. ${ }^{5}$ During the height of what has now been labelled the 'Great Recession,' working class problems were scarce in electoral rhetoric. It is true that bourgeois class privilege, including lowering taxes (especially corporate income tax rates) and decreasing 'regulation' for for-profit business was a major policy plank for many parties in both elections. But, this class privilege was not discussed explicitly in class terms. Instead, bourgeois interests were presented as 'the general interest'.

Yet despite this absence of a discussion of class, as such, working class concerns were not an entirely marginal issue. Rather, both electoral campaigns had conservative political parties using a particular kind of cultural class rhetoric, with a populist touch, in an attempt to gain votes. In the United States, the Republicans emphasized their story of 'Joe the Plumber' and in, Canada, the Conservatives blasted opposition parties for their support of arts funding, claiming that "ordinary Canadians don't support the arts." That the Republicans and Conservatives would use the language of populist working class politics seemed counter-intuitive to some, as these parties are both very closely linked with corporate interests and do not promote the economic interests of the working class. Yet, while the Republicans and Conservatives are bourgeois parties, simple electoral math dictates that they must appeal to the majority of voters in the working and 'new middle'

Aronowitz (1998) From The Ashes of the Old: American Labor and America's Future for an Analysis of American Exceptionalism. For Canada, readers are direct to Brodie and Jenson (1991) Crisis, Challenge and Change: Party and Class in Canada; Lambert et. al. (1987) "Social class, left/right political orientations, and subjective class voting in provincial and federal elections"; Pammett (1987) "Class voting and class consciousness in Canada".

${ }^{3}$ The term 'middle class' remains elusive for the study of class relations. In many senses, it is a pure sociological invention: the 'middle class' does not relate class position to the means of production. Nevertheless, the 'middle class' has become important to the study of electoral sociology for social democratic parties. Moschonas $(2002,44)$ notes that 'middle classes' derive their origin from 'a scalar structure of social stratification.' These 'new middle classes' tend to be salaried professionals, often employed in the public sector.

${ }^{4}$ The issue of social democratic labour parties shifting their rhetoric and appeal away from the working class is certainly not a phenomenon limited to the NDP in Canada. For discussions of this shift within the NDP see, for example, Carroll \& Ratner (2005), Janson \& Young (2005), and Beaton (2000). The broader context can be found in Moschonas (2002) and Upchurch et. al. (2009), amongst others.

${ }^{5}$ Unless otherwise noted, all further references in this paper to the "American election" refer to the American federal election of 2008, and all references to the "Canadian election" refer to the Canadian federal election of 2008 . 
class to get elected.

This paper examines how neoliberals, especially conservative political parties, talk about class and how they seek support among the traditional working class, that is, among those who must sell their labour power for a wage or salary in order to survive. In particular, this research note describes how the Republicans in the United States and the Conservative Party in Canada appealed to that segment of the working-class who are either semi-skilled or unskilled by using class as a cultural variable.

Although this paper focuses on the 2008 elections, this utilization of class as a cultural variable not as an isolated political incident, but indicative of the mobilization of a broader neoliberal ideology. When small-c conservative parties use the language of class, they are not referring to class as an economic or social variable. Neoliberal conservative parties do not connect 'class' to your relationship to the means of production or even to your relative economic standing. Class, to neoliberals, has been redefined as a cultural matter, an expression of values, taste, aesthetics, or anti-elitism. This reconception of class as a purely cultural variable has allowed small-c conservative parties to tap tensions within the working class and appeal to its populist elements, so defusing its potential as a force for genuine working class politics. ${ }^{6}$

\section{Neoliberalism, Class, and Culture}

Neoliberalism is both a theory and a set of policies and practices. As a theory, neoliberalism proposes that human well-being can be advanced by liberating individual entrepreneurial freedoms and skills within an institutional framework characterized by strong private property rights, free markets and free trade (Harvey 2005, 2). According to Harvey, neoliberalism is a specific type of class-based rule that has enabled capital to restore its dominant position, eroded during the era of Keynesian Welfare States. In practice, this has entailed the privileging of market relationships, a process that has involved the active re-structuring of many different aspects of social life, from labour relationships through to how people think about those relationships.

Yet, consent to the class based rule of neoliberal capitalism did not spontaneously appear. Neoliberalism has built what Gramsci referred to as hegemonic 'common sense', but of a particular kind, emphasizing the supremacy of the individual and individual action. This individualistic ideology was, of course, famously summarized by Thatcher when she claimed that "There is no such thing as society. There are individual men and

\footnotetext{
${ }^{6}$ This dynamic may have something in common with extreme right-wing populist efforts, which seek to split the working class along racial fault lines, obscuring class as a political economy fact and focussing on the supposed racial but also cultural 'otherness' of elements of the working class. This research note does not explore this potentially parallel dynamic.
} 
women, and there are families." Indeed, Giroux stresses that neoliberalism rests on "a growing sense in the popular imagination that citizen involvement, social planning and civic engagement are irrelevant" $(2008,131)$ : the individual participates in the world as an individual, not as a citizen participating in a collective, social project.

Like Giroux, Sennett argues that in the 'new capitalism' dependency is viewed with disdain and the heroic individual, able to constantly re-invent himself to meet the needs of capital, is celebrated $(2006,4)$. Yet, Sennett also highlights another dynamic, which he calls ressentiment:

the belief that ordinary people who have played by the rules have not been treated fairly. It is a social emotion that strays from economic origins and, in part, explains why so many workers once centre-left have moved far to the right, translating material stress into cultural symbols (ibid, 132 - 133).

In other words, the 'unfairness' of daily life experienced by the working class is not analysed on a class basis that might enable this experience of unfairness to become a source of working class solidarity. Instead, working class individuals resent real or imagined others who 'rip off the system' while they themselves struggle, as individuals and as families, on an everyday basis. Often those who are resented are racialized others, but they may also be liberal elites, who are resented for acting in concert with racialized others.

Of course, these neoliberal ideas and their use by neoliberal political parties predates the 2008 election. The Republican Party, especially under Reagan, sought an alliance with the Christian Right. It appealed to the cultural nationalism of the white working class, and their "besieged sense of moral righteousness" (Harvey 2005, 49-50). On this basis, the Reagan Republicans were able to build a strong base of working class support, against the working class' own material interest. The key to this was the construction of a working class identity based on cultural symbolism and morality, not upon the reality of economic conditions. The Republicans became a party that motivated its new working class base via rhetoric that basically amounted to a "defence (of the) sanctity of white suburban family life" (Davis 2007, 170). Widespread support of the Reagan Republicans from blue collar constituencies demonstrated that where economic conservatives had dismally failed, social conservatism, racism (and patriotism) provided dramatic success (ibid, italics added).

"Class, conservatives insist, is not really about money or birth or even occupation. It is primarily a matter of authenticity" (Frank 2004, 113). Working class authenticity is rooted in the idea of the working class as hard-working, employed, able bodied men. This conception sees the working class not struggling in an economic sense, but struggling against elites that are critical of a working-class lifestyle. It sees the working class opposed 
to liberal elites who "eat imported cheese, drive Volvos, and drink lattes" (Ibid, 17). The economic class position of these 'elites' is never clarified: it is purposely left vague. This allows conservative rhetoric to blur the lines between working class and middle class, positioning the 'authentic' working class in a cultural class war with the 'inauthentic' elites. The problem for the working class is neither "capitalism nor the neoliberalization of culture, but the 'liberals' who used excessive state power for special groups (blacks, women, environmentalists, etc.)" (Harvey 2005, 50).

The Republican Party in the United States, the Conservative Party in Britain under Thatcher, and in Canada, the Reform Party and the Canadian Alliance, the forerunners to the modern Conservative Party of Canada, have all built a class politics based partly on working class resentment of supposed liberal elites. At the same time, their vision of the 'emancipation' of the individual through hard work in 'free markets' serves the broader neoliberal economic project by discouraging genuine working class-based identification and solidarity.

\section{'Joe The Plumber'}

Samuel Joseph Wurzelbacher, better known as 'Joe The Plumber', became a major Republican symbol of the American working class, as the Republicans defined it, during the American election. Joe The Plumber first appeared on 12 October, 2008 when Democratic presidential candidate Barack Obama was campaigning in Ohio. Wurzelbacher confronted Obama over the candidate's tax plan, accusing him of raising taxes on the working class: "I'm getting ready to buy a company that makes 250 to 280 thousand dollars a year. Your new tax plan's going to tax me more, isn't it?" (Rohter 2008). The question, and ensuing exchange with Obama, was captured on tape by ABC News, and propelled Wurzelbacher to national fame. Soon, Joe The Plumber / Wurzelbacher would become a Republican symbol for tax relief. Later, on the 15 October, 2008, the final presidential debate was held. During the debate, Republican candidate John McCain made numerous references to Joe The Plumber, using him an example of a hard working American striving for the American Dream. McCain argued that Obama's tax plan was not in the economic interests of the American working class, and that it only served to hinder those who were working hard to get ahead. Republicans, on the other hand, championed the economic interests of working class individuals like Joe by promising lower taxes.

A closer examination of Joe The Plumber shows exactly what the Republican definition of 'working-class America' is. First, Joe The Plumber is a white male from middle America. Second, while Joe The Plumber was employed as an independent contractor, he had aspirations of owning his own business so that he could "take home $\$ 250000$ - \$280 000" a year. Of course, working-class America is not predominantly 
white and male. While white men can certainly be found in the working class, so too can women and racialized workers. Moreover, the overwhelming majority of Americans do not take home $\$ 250000$ - \$280 000 a year. Indeed, 28 million Americans lived below the poverty line in 2007 (United States Census Bureau 2008). Further, Joe The Plumber sought to purchase his own business- an aspiration for accession into the business class that fits with the image of the heroic entrepreneur celebrated by neoliberals, but that is hardly the reality for most working class people in the United States. While Samuel Joseph Wurzelbacher was a real, specific person who asked a pointed question to Obama, Joe The Plumber was a carefully constructed idea - an idea of a working-class America that simply does not exist.

One of the additional, central messages of the trope of Joe the Plumber, as an authentic, working class American, is that his difficulties in amassing personal wealth can be attributed to the high taxes supported by 'liberal elites.' His economic struggles are not symptomatic of the ordinary hardship of contemporary working class lives nor are they a reflection of low levels of class mobility in America -- nor even a consequence of his own failings, which is the usual neoliberal explanation for economic hardship. In this way, class resentment around taxes and a celebration of the heroic individual replaces analysis of working class realities, grounded in the ordinary workings of an unequal capitalist system. ${ }^{7}$

\section{'Ordinary Canadians Don't Care About The Arts'}

During the 2008 federal election, the Liberals, NDP and Bloc Québecois attacked Prime Minister Stephen Harper by pointing that during their first term in government, the Harper Conservatives cut \$45 million from arts and cultural spending in Canada. Yet, Harper defended the cuts saying the government was going to stop "funding things the people actually don't want" (Bradshaw 2008). He attempted to paint the three opposition parties as elitist, in their defense of the arts, and out of touch with 'ordinary Canadians':

You know, I think when ordinary, working people come home, turn on the TV and see... a bunch of people at a rich gala all subsidized by the taxpayers, claiming their subsidies aren't high enough when they know the subsidies have actually gone up, I'm not sure that's something that resonates with ordinary people (CBCNews 2008).

\footnotetext{
${ }^{7}$ Although Republicans used Joe The Plumber as an example of 'hard-working America', both the Republicans and Democrats shunned explicit references to the 'working class.' In the three presidential debates, the term 'middle class' was used twenty-eight times, while 'working class' was not used at all. The term 'main street America' which has become code for 'middle class' was used in the debates nine times more. In contrast, 'poverty' received nary a mention, and 'low income' and 'the poor' were only used once (Loury 2008).
} 
According to the Conservatives, arts and culture funding was simply not something the working class cared about. Rather, the arts are an activity for elites. ${ }^{8}$

The Conservatives insisted that artists are dependent on the state for funding, unlike everyday working class Canadians. This echoes neoliberal efforts to exploit the tension between private and public sector workers, by portraying public sector workers as parasitic, living off the taxes paid by the more "honest" members of the working class working in the private sector (workers who moreover often lacks the benefits and relative job security of the public sector). At the same time, it builds upon the neoliberal political suspicion of any activity that is not based in the market. Art for the sake of cultural advancement does not contribute to the economy and so is 'useless' - and by extension so are publicly funded artists.

Of course, small-c conservatives and neoliberals have employed similar arguments before, arguing that it was "unacceptable for taxpayers' money to support museum exhibitions that included 'controversial', 'sacrilegious', 'blasphemous' and 'filthy' works" (Fox 2001, 46). And indeed, Reagan cut federal arts funding in America by 10\% in 1981, and since 1992 the American Congress has made steady cuts to the National Endowment of the Arts (ibid, 43 - 47). In the instance discussed here, the Conservative Party employed a similar logic to suggest that artists and the parties that supported them were out of touch with working class Canadians.

\section{Conservative Parties and their Conception of Class}

Both the Conservatives and the Republicans made indirect appeals to the working class in the 2008 elections. In both cases, the appeal to the working class was grounded in materialist issues: taxation as main terrain of struggle for income redistribution. Of course, both parties advocated lowering taxes, which is arguably against the economic interests of the working class, as taxes provide the funding for state provided social programs that benefit the working class. While the campaign issues were materialist, the conception of the working class used by these parties was not. The Republican's symbol of the American working class was white, male, and made significantly more than the average American worker. The Conservative Party of Canada portrayed the working class as hard-working Canadians who would rather watch TV than see their tax dollars subsidise elite artists. In both these cases, the conception of class that the parties appealed to was cultural, not economic.

Both parties used the 'logics' of neoliberalism in their appeal to the working

\footnotetext{
${ }^{8}$ Of course, the majority of Canadian artists are themselves working people. Indeed, the average artists in Canada made \$20,000 in 2007 (Maranda 2008).
} 
classes. They emphasised individualism: Joe The Plumber as one individual who was pursing the American Dream and 'useless' artists who needed to take individual responsibility, rather than relying on state funding. Both the Republicans and the Conservatives positioned themselves as the champions of heroic working class Americans and Canadians who were attempting to get ahead, but could not because of taxation. The parties would emancipate the working classes by lowering taxes, reducing government involvement in the market, and countering liberal elite ideals and taxes that preventing the working class from getting ahead and pursing their own market activity. The arguments both parties made were very similar: they both wished to reduce state spending in the market, champion individual rights and freedoms, and to act as a counterbalance to liberal 'elitism.'

The goal of the conservative parties here is indicative of a larger phenomena of politics under neoliberalism: depoliticizing class. Neoliberal politics see the individual as paramount; individual action is celebrated while collective action is actively discouraged. Collective economic action is anathema to neoliberal policies like market deregulation, lower corporate taxes, and private property rights (Teeple 2000). Reconstituting class as a cultural variable helps the neoliberal project. Class is no longer a concept relating to one's relationship to the means of production or economic well being but is instead an individual identity. Class is held not collectively, but rather individually. The assault on the working class does not come from capitalists extracting surplus value, but rather from 'liberal elites' (another purposely poorly defined term) who disparage working class culture as 'unsophisticated' and crude.

While right wing parties have reconstituted class as a cultural identity, not a socioeconomic one, there has been virtually no response from the electoral left. In the United States the Democrats have long abandoned the economic language of class (Frank 2004, 245-248). Harvey argues that while the Republican Party could mobilize massive financial resources to convince a popular base to vote against its material interests on cultural or religious grounds, the Democrats could not afford to attend to the material needs of its traditional popular base for fear of offending capitalist class interests $(2005,51)$. During the 2008 campaign Obama made many references to the middle class, but not the working class. The Democrats seem content to accept class as a cultural identity, and use the language of neoliberal economics and politics.

In the Canadian case, neither the Liberals or the NDP attempted to define 'ordinary Canadians' or some variation of working Canadians or the working class, in economic terms. This, however, is not out of step with the politics of either party. The Liberals have always been a bourgeois party which supported big business, and have never supported the class interests of the working class (Brodie \& Jenson 1991, 3). While the Liberals often campaign from the left, and govern from the right, this campaigning is often around cultural or social policy, or 'soft' economic issues like supporting public health care. The NDP has been slowly moving away from any pretence of being a 
working-class party. The NDP has usually focussed their federal campaigns on various issues including health care, environmental protection, and accountability. The party has shifted in its rhetoric away from the working class, claiming to be a party for "all Canadians" (in 1997), "working families" (in 2000) and recently for "people” (in 2006). During the Great Recession in 2008 and 2009, the NDP called for a roundtable for 'middle class families.' The NDP maintains nominal ties with organized labour in Canada, and some unions in Canada encourage members to support the party - this has kept the NDP to the relative left of the other major parties in Canada, and has contributed, in part, to the party being branded as a "socialist" party by the Conservatives, the capitalist class, and the certain segments of the capitalist friendly media. While NDP platforms and policies may be to the left of the other mainstream parties in Canada, the party still ascribes to neoliberal logic, and has long abandoned the language and politics of class.

\section{Conclusion}

Interestingly, in both cases the conservative appeal to working class voters failed: Obama won the Presidential election and the Conservative Party was unable to secure a majority government. The Conservative Party of Canada was unable to secure a majority government in 2008 largely because it was unable to break through into vote and seat rich Ontario and Quebec. The besieged Liberals were able to hold on to enough seats in these two provinces to deny the Conservatives the majority they so dearly sought. While the Canadian election was seen largely as a referendum on both the Harper government, elected in 2006, and on Liberal leader Dion, Christopher Dornan makes the argument that it was indeed Harper's attempt to cut federal spending to the arts that cost him the election. Dornan suggests that the attempt to cut art funding turned Quebec against the Conservatives, and thus denied them the majority they sought $(2009,13)$. Indeed, the largest rally of the election was held in Montreal to protest the arts cuts (ibid). This suggests, ironically, that ordinary Canadians do care about the arts. ${ }^{9}$

The case of Joe The Plumber is more complex. While a number of factors contributed to Obama's win over McCain, none did more so than the record numbers of racialized Americans who voted overwhelmingly for Obama: 95\% of African-Americans, $66 \%$ of Latinos, $61 \%$ of Asians and $65 \%$ of voters self-identified as "other" voted for Obama (Metzgar 2009). Metzgar estimates that between $83 \%$ to $86 \%$ of the nonwhite

\footnotetext{
${ }^{9}$ Within days of Stephen Harper making the claim about 'Ordinary Canadians' a group on Facebook was created entitled "Ordinary Canadians DO SUPPORT the Arts, Mr. Harper. You are dead wrong." The group has over 61000 members. Some tens of thousands of individuals, many of whom must be working class Canadians, rejected Harper's populist appeal, showing the contradictions of working class culture and the limits of such populist politics.
} 
working class in the United States voted for Obama in 2008. This can be contrasted to the between $51 \%$ and $56 \%$ of the white working class who voted for McCain in 2008. Indeed $55 \%$ of whites, regardless of class location, voted for McCain in 2008 (ibid). This suggests that on some level, the appeal by the Republican party to the working class as they defined it - white, male, employed, able-bodied and heterosexual - worked on some level. The Republicans were able to motivate a majority, albeit a slim one, of working class voters to vote against their economic interests in 2008. The extent to which Joe The Plumber contributed to this is uncertain. ${ }^{10}$

In sum, in the 2008 federal elections in the United States and Canada, neoliberal political parties define the working class along cultural lines. The working class is imagined as a group of hard working individuals, earning a middle-class income, who do not ascribe to 'elite' values and lifestyles. Voting for neoliberal parties, then, defends a 'traditional' way of working class life. This vision of class highlights the individual and downplay the real nature of class as a common social experience grounded in unequal relationships that define capitalism. In turn, this neoliberal cultural ideology of class helps build support for neoliberal and small-c conservative political parties and more broadly, creates a new common sense that justifies the class based rule of neoliberalism.

\section{References}

Archer, Robin. 2007. Why is There No Labor Party In The United States? Princeton: Princeton University Press.

Aronowitz, Stanley. 1998. From The Ashes of the Old: American Labor and America's Future. Boston: Houghton Mifflin Company.

Beaton, James. 2000. "Crowding The Centre: The Third Way and the NDP" in Canadian Dimension 34, iss. 6.

Bradshaw, James. 2008. "Harper plays populist tune on arts cuts" in The Globe and Mail. Accessed online at http://www.theglobeandmail.com/news/politics/article708298.ece on 18 Feb 2010.

\footnotetext{
10 The ascension of the Tea Party movement in the United States suggests that the Republican party is still attempting to appeal to the working class through both economic and cultural strategies. The effect, or lack of effect, that the Tea Party has on the 2010 midterm elections and 2012 general election in the United States should be of great interest to those concerned with the cultural aspects of neoliberalism and electoral politics.
} 
Brodie, Janine \& Jane Jenson. 1991. Crisis, Challenge and Change: Party and Class in Canada Revisited. Ottawa: Carleton University Press.

Carroll, William K. \& R. S. Ratner. 2005. Challenges and Perils: Social Democracy in Neoliberal Times. Halifax: Fernwood.

CBC News. 2008. "Layton and Duceppe protest culture cuts in Montreal." Accessed online at http://www.cbc.ca/news/canadavotes/story/2008/09/23/oppositionarts.html 19 Feb 2010

Davis, Mike. 2007. Prisoners of the American Dream: Politics and Economy in the History of the U.S. Working Class. London: Verso.

Dornan, Christopher. 2009. "The Outcome in Retrospect" in The Canadian Federal Election of 2008, eds: Jon H. Pammett \& Christopher Dornan. Toronto: Dundurn Press.

Frank, Thomas. 2004. What's The Matter With Kansas? How Conservatives Won The Heart of America. New York: Holt.

Fox, Danielle. 2001. "Art” in Culture Works: The Political Economy of Culture, ed: Richard Maxwell. Minneapolis: University of Minnesota Press.

Giroux, Henry A. 2008. Against The Terror of Neoliberalism: Politics Beyond the Age of Greed. London: Paradigm Publishers.

Goldner, Loren. 2003. "On the Non-Formation of a Working-Class Political Party in the United States, 1900 - 45” in Historical Materialism, volume 11:4.

Hall, Stuart. 1988. The Hard Road to Renewal: Thatcherism and the Crisis of the Left. London: Verso.

Harvey, David. 2005. A Brief History of Neoliberalism. Oxford: Oxford University Press.

Janson, Harold and Lisa Young. 2005. "Solidarity Forever? The NDP, Organized Labour, and the Changing Face of Party Finance in Canada." Conference paper presented to the Annual Meeting of the Canadian Political Science Association London, Ontario, June 2-4, 2005.Available online at www.cpsa-acsp.ca/papers2005/Jansen.pdf accessed 02 Feb 2011. 
Lambert, Ronald D., James E. Curtis, Steven D. Brown \& Barry J. Kay. 1987. “Social class, left/right political orientations, and subjective class voting in provincial and federal elections" in Canadian Review of Sociology and Anthropology. 24(4).

Laycock, David. 2002. The New Right and Democracy in Canada: Understanding Reform and the Canadian Alliance. Oxford: Oxford University Press.

Lipset, Seymour Martin \& Gary Marks. 2000. It Didn't Happen Here: Why Socialism Failed in the United States. New York: W. W. Norton \& Company.

Loury, Alden. 2008. "Why Do We Hate The Poor?" in Huffington Post. accessed online at http://www.huffingtonpost.com/alden-loury/why-do-we-hate-thepoor_b_140586.html on 18 Feb 2010.

Maranda, Michael. 2009. Waging Culture: The socio-economic status of Canadian visual artists. Report prepared for The Art Gallery of York University. Available online at http://theagyuisoutthere.org/everywhere/?p=1443 accessed 19 Feb 2010.

Metzgar, Jack. 2009. “The White Vote in 2008: Most of Us Aren't as Bad as We used to Be." Conference paper presented at The 2009 Working Class Studies Association Conference held at The University of Pittsburgh, Pittsburgh, Pennsylvania. 3 - 6 June 2009. Available from the author at jmetzgar@roosevelt.edu

Moschonas, Gerassimos. 2002. Trans. Gregory Elliot. In The Name of Social Democracy: The Great Transformation: 1945 to the Present. London: Verso.

Pammett, Jon H. 1987. "Class voting and class consciousness in Canada" in Canadian Review of Sociology and Anthropology. 24(2).

Panitch, Leo \& Colin Leys. 2001. The End of Parliamentary Socialism: From New Left to New Labour. London: Verso.

Rohter, Larry. 2008. "Real Deal on 'Joe The Plumber' Reveals New Slant” in The New York Times. 16 Oct 2008. Accessed online at http://www.nytimes.com/2008/10/17/us/politics/17joe.html?_r=1 on 18 Feb 2010.

Sassoon, Donald. 1996. One Hundred Years of Socialism: The West European Left in the Twentieth Century. New York: The New Press.

Sennett, Richard. 2006. The Culture of the New Capitalism. New Haven: Yale University 
Press.

Teeple, Gary. 2000. Globalization and the Decline of Social Reform: Into the Twenty-First Century. Aurora: Garamond.

Upchurch, Martin, Graham Taylor, \& Andrew Mathers. 2009. The Crisis of Social Democratic Trade Unionism in Western Europe: The Search For Alternatives. Burlington: Ashgate.

United States Census Bureau. 2009. "Poverty: 2007 and 2008 American Community Survey." Accessed online at http://www.census.gov/hhes/www/poverty/poverty.html on 18 Feb 2010. 